\title{
DIDRO Project - New means for surveying dikes and similar flood defense structures
}

\author{
Thibaut Miquel $^{1 \mathrm{a}}$, Jean-Luc Sorin ${ }^{2 \mathrm{~b}}$, Jean Maurin $^{3 \mathrm{c}}$, Rémy Tourment ${ }^{4 \mathrm{~d}}$, Frédéric Pons ${ }^{5 \mathrm{e}}$, Jérôme Bohard ${ }^{1 \mathrm{f}}$, Jean-Frédéric \\ Biscay $^{6 g}$ \\ ${ }^{1}$ Redbird- 16 rue de la Comète - 75007 Paris \\ ${ }^{2}$ Ifsttar centre de Nantes - Route de Bouaye - CS4, 44344 Bouguenais Cedex \\ ${ }^{3}$ DREAL Centre-Val De Loire 5, avenue Buffon - CS 96407 - 45064 ORLÉANS - CEDEX 2 \\ ${ }^{4}$ Irstea, Centre d'Aix en Provence, 3275 route Cézanne, CS 40061, 13182 AIX EN PROVENCE Cedex 5, France \\ ${ }^{5}$ Cerema - Direction Territoriale Méditerranée, Av. A. Einstein - 13593 Aix-en-Provence \\ ${ }^{6}$ ENTENTE VALABRE, Centre Francis Arrighi - Domaine de Valabre - RD7 - 13120 Gardanne
}

\begin{abstract}
The 36-month-long DIDRO project seeks to bring existing developments on remote sensing by drone on the scope of the project: dikes surveys as routine inspection or in relation to a flood crisis. Drone offers a new complementary means of surveying which can map broad areas efficiently while being more flexible and easier to operate than other airborne means. The system shall consist in a drone vector, in dedicated sensors (such as LiDAR, visible, near-infrared and thermal infrared optics), in data processing models with analytics specific to dikes surveying and finally in a GIS capitalizing all appropriate data to dikes managers.
\end{abstract}

\section{Introduction}

Flood risk has been identified as the most sensitive of natural hazards in France. Indeed, the last 20 years have been marked by dramatic events such as the Xynthia storm in February 2010 (47 deaths, $€ 2.5$ billion of direct damage and $200 \mathrm{~km}$ of dikes to rebuild). The 1993-94 events in the Camargue delta, 1999 events in the Aude area and the 2002-2003 events on the Rhône and its tributaries are examples among others of the risks of floods and damages resulting from the failure of river dikes. A dike failure could trigger a much more dangerous water wave than the flood submergence the protected populations and sensitive sites are subtracted from.

The French Ministry of Ecology, Sustainable Development and Energy aims at reducing the risks and damages of flood event. Levees in France have been found to be generally fragile, leading the French State to strengthen the regulation on the control of dikes, and leaving dikes managers to support new safety requirements. The implementation of those new regulations has highlighted, besides the disparity of

\footnotetext{
amiquel@getredbird.com

b jean-luc.sorin@ifsttar.fr

c jean.maurin@developpement-durable.gouv.fr

d. remy.tourment@irstea.fr

e. frederic.pons@cerema.fr

f. bohard@getredbird.com

g.jf.biscay@valabre.com
}

resources, a lack of staff. To better structure the dike managers and to help dikes managers coping with all the challenges under their responsibility, France Digues association was created in 2013.

Dikes inspection methods nowadays require significant human and financial resources. DIDRO project (acronym for Dikes surveying by drones) aims at developing a solution of dikes survey by instrumented drone. The 36month-long DIDRO project shall create a comprehensive service: a drone vector (any brand, any model thanks to the versatility of the sensors), dedicated sensors (such as LiDAR, visible, near-infrared, thermal infrared optics), appropriate processing softwares and finally a GIS database capitalizing all appropriate measurements to dikes managers. Market access is the responsibility of Redbird, the future DIDRO service provider, with the help of Ifsttar (drone expertise and hazard risk), France Digues (dikes managers association), Irstea and Cerema (dikes expertise, remote sensing data acquisition and processing).

DIDRO project was initiated by the DREAL Centre (French Regional Directorates of Environment, Planning and Housing - Centre Region) and the DRI (Innovation 
\& Research Directorate) of the French Ministry of Ecology, Sustainable Development and Energy. It has a French public support of about 2 M€ through the 19th call for projects of the Fonds Unique Interministériel. The project consortium combines four private firms and five laboratories.

\section{Dikes management in France}

\subsection{Types of dikes}

Dikes are "raised, predominantly earth, structures that are not reshaped under normal conditions by the action of waves and currents, whose primary objective is to provide protection against fluvial and coastal flood events along coasts, rivers and artificial waterways" (International Levee Handbook, CIRIA, 2013)

The dikes are primarily intended to prevent water from invading natural floodplains. There are numerous kinds of dikes, be it riverine or coastal dikes, with a continuous or discontinuous water loading. The antiflood dikes are only requested during high water periods whereas the waterways levees are permanently constrained by the wave action and permanent presence of water (internal circulation).

Dikes are sometimes century-old and their precise constitution is often unknown. They were most often built with various materials available on-site and have evolved over time (collars, repairs, etc.). Many of them had been derelict for a period ranging from the midnineteenth century until the late twentieth. Although they are properly maintained, their behaviour in times of high water remains uncertain, not fully guaranteeing the protected areas at any water level. The occurrence of a major event could trigger serious damages or even breaks in some parts of these structures, causing catastrophic flooding including human losses. Finally, mechanisms such as internal erosion can lead to the breach of the dike and thus the failure of its protective function even if the water level is not high enough for overtopping.

The continuous monitoring of dikes is therefore a major imperative. In France, there are about $8600 \mathrm{~km}$ of official dikes, out of which $510 \mathrm{~km}$ are against marine submersion, protecting from hundreds of thousands people to millions people if the other flood defence structures similar to dikes are taken into account.

\subsection{The lack of staff to face strengthened regulatory requirements}

The dike managers are responsible for surveillance operations, diagnostic and hazard studies. The implementation of new regulatory requirements has highlighted, besides the disparity of resources, a lack of staff and funds. For example, depending on the different districts, the French State has reduced the number of its field agents from $2 / 3$ to $4 / 5$ th of its initial workforce in 15 -25 years.

Furthermore, new regulatory requirements involve additional costs of implementation in the absence of innovative methods improving the efficiency of dikes inspection. This can severely lower the amount dedicated to repairs, which results in a counterproductive effect on safety.

For example, in the Loire valley, dammed and urbanized areas such as Orleans, Tours and SaumurAngers are highly exposed to extreme flooding. The DREAL Centre safety impact analysis estimates for such centennial flood: 30,000 endangered residents and 230,000 flooded, 36 sensitive facilities including 4 hospitals and clinics, 13 nursing and 2 train stations.

\section{Current means for dikes surveying and the DIDRO innovation}

The general framework of inspection, diagnostic and dikes risk analysis is presented in Chapter 5 of the International Levee Handbook (CIRIA, 2013), these activities are based largely on regular monitoring. All sources or indicators of disorders within a dike are sought. It should be noted here that the disorders may appear gradually or suddenly. Without being exhaustive, these disorders are: internal heterogeneity, impairments due to embedded constructions, pipes, roots of trees, burrows, seepage or subsidence in areas of karst. The term surveying means detection and identification of disorders or phenomena which can lead to disarrays, this term also includes their measurement, in order to diagnose and assess their consequences.

The authors emphasize that the DIDRO project is in its development stage, delivering the expected outcome remains a challenge to achieve.

\subsection{Methods of dikes surveying and DIDRO}

As mentioned in the introduction, the most widespread methods for dikes surveying rely on visual recognition and topography while other auscultation methods such as thermometry piezometry, optical fiber are also used. There are also non-destructive inspections of profiling and geophysical imaging, such as: seismometer, magnetotelluric sounding, electrical resistivity tomography and ground penetrating radar. In some cases, topography tools are used such as an airborne LiDAR.

The disruption initiated by DIDRO concerns a methodology of inspection, recognition and/or auscultation. It is a system innovation as well as an innovation in the way it will be used. It aims at bringing together several existing innovations in various fields and leveling up their technology readiness level to provide an answer to the needs of dikes managers. The underlying technologies of the DIDRO project will indeed evolve from a Technology Readiness level (TRL) 4 to TRL 7. The system consists in a drone vector (compliant with a wide range of models, thanks to the versatility of the sensors), of dedicated sensors (such as LiDAR, visible, near-infrared and thermal infrared optics), of appropriate processing software and finally of a GIS database 
capitalizing all appropriate measurements to dikes managers.

DIDRO shall lead to a large-scale inspection tool which improves the detection rate of disorders and provides a large array of remote-sensed measurements. It shall thus ease the identification of those disorders. Its multidisciplinary approach is based on a multi-sensor imaging instrumentation (LiDAR, Visible and Near Infrared (VNIR), thermal Infrared (IR), geophysical sensors) and associated analysis of multi-spectral signatures.

DIDRO builds on the experience gained in the following previous projects:

- The DIGSURE project: since 2009, IRSTEA research scientists have been defining a norm of dikes performance indicators and integrating them in a GIS.

- $\quad$ CNR and IGN have been modelling dikes by light airborne photogrammetry. They aim at improving its centimetric accuracy.

- CEREMA Normandie-Centre and IFSTTAR have been developing a multidisciplinary approach combining geophysical and geotechnical methods for 3D dikes surveying.

- L'Avion Jaune markets a light UAV-borne LiDAR, coupled with a differential GPS and an inertial central unit which restores the topography, even under vegetation.

- CARDIGUES, a model computing the likelihood of dikes breach per 50-meter long section. It has been developed and tested for the state-owned dikes of the Loire valley

- SIRSDIGUES, GIS tool for dikes management ordered by France Digues and developed by Geomatys

- IFSTTAR is one of the pioneers in the monitoring of hydraulic environment by drone. With respect to both projects listed below (DERKX \& Sorin, 2015), DIDRO shall improve its multi-spectral detection capabilities while using a lighter payload:

- The ANR Quadro project (achieved and patented) concerns algal proliferation in urban lakes.

- $\quad$ The ANR OSS-CYANO project (pending, launched in May 2014), aims at detecting cyano bacteria through miniaturized reflectance sensors.

\subsection{Routine inspections and inspections in relation to a flood event}

Two contexts for dikes surveying are considered here: routine inspection and inspection before / during / and following a flood event.

Routine inspection includes: basic scheduled inspection (Visite de Surveillance Programmée) for a continuous control of the dikes (every two months for example), and detailed technical inspection (Visite Technique Approfondie) every 1 to 5 years depending on the regulatory dike class. Dikes are indeed classified into four classes, according to their height and the number of people leaving in the leveed area. Reports in a standardised form are issued, including conclusions on the safety level of the structure and follow-up actions to be taken. It is very difficult to estimate its cost taking account of the diversity of dykes and the number of managers among others. According to a recent survey directed by France Digues (France Digues, 2014), representing $16 \%$ of the total length of dikes in France, costs ranges from 1000 to $4000 € / \mathrm{km}$ for a length below $5 \mathrm{~km}$ to 100 to $600 € \mathrm{HT} / \mathrm{km}$ for longer length.

The inspection before / during / and following a flood event is linked to the actual features of the event. The crisis management team often faces large difficulties to ensure the safety of the emergency response teams on site. Accurate diagnosis is thus essential and requires detailed and exhaustive information. During a flood crisis, as a provider of real-time information at a high update rate, the drone DIDRO shall serve as a flying patrol, allowing helicopters to devote themselves to critical operations requiring a heavy payload, such as people rescue and intervention along a dike section presenting a serious risk of breach. Aerial imagery by drone brings a global vision of the crisis zone and quickly identifies the location of materials and sensitive human issues. In this regard, one of the major technological challenges is the drone's ability to fly in conditions of strong winds gusting (with peaks up to $80 \mathrm{~km} / \mathrm{h}$ ).

\subsection{Comparison of ground crews, ground vehicle, helicopter and drone as means for dike inspection}

The inspection by ground crews is expensive in time and limited in a context of human resource reduction. Manual observations must then be recorded in a GIS.

Unsatisfied by the high frequency of detailed technical inspections (VTA - Visite Technique Approfondie), some dikes managers opt for a makeshift solution by replacing one VTA on two by an annual synthesis of the monthly basic scheduled inspection. To cope with this solution deemed unsatisfactory in terms of safety, especially in times of crisis, DREAL Centre (French Regional Directorates of Environment, Planning and Housing - Centre Region) initiated the development of a patrol vehicle with cameras in the visible, nearinfrared and infrared ranges as well as a system of alert transmission. However, such ground-based system, currently being developed by Cerema (CECP Angers), has the defect of a biased vision of the observed dike and thus cannot produce a comprehensive survey of the structure. Ne limit is the physical access of a vehicle near dikes.

Drone here is an innovative technical solution that can best respond to this problem, in addition to avoiding the experts to go on-site in unsafe areas. In addition, the deliverables of this rapidly executed mean of surveying are directly integrated in the GIS of the dike manager. The drone system thus produces a comprehensive and accurate survey, directly integrated into the decision- 
making process. Subject to the condition of having a high performance drone, real-time expertise would be feasible and would thus anticipate failures and limit its effects. It would also allow the Civil Protection to order safety measures, up to the evacuation of populations.

\begin{tabular}{|c|c|c|}
\hline $\begin{array}{l}\text { Existing } \\
\text { solutions }\end{array}$ & Strengths & Weaknesses \\
\hline $\begin{array}{l}\text { Pedestrian and } \\
\text { visual } \\
\text { observations }\end{array}$ & $\begin{array}{l}\text { Staff "on the spot", } \\
\text { Good level of } \\
\text { expertise }\end{array}$ & $\begin{array}{l}\text { Cost, lack of } \\
\text { perspective on the } \\
\text { subject, not } \\
\text { exhaustive, } \\
\text { insufficient } \\
\text { traceability of the } \\
\text { observations }\end{array}$ \\
\hline $\begin{array}{l}\text { Instrumented } \\
\text { vehicle }\end{array}$ & Cost of the carrier & $\begin{array}{l}\text { Limited coverage, } \\
\text { biased vision, poor } \\
\text { accessibility } \\
\text { during flood event }\end{array}$ \\
\hline $\begin{array}{l}\text { Instrumented } \\
\text { helicopter }\end{array}$ & $\begin{array}{c}\text { Flexibility and } \\
\text { versatility of uses } \\
\text { Quality of the } \\
\text { information from } \\
\text { multi-spectral imagers }\end{array}$ & $\begin{array}{l}\text { Cost, medium- } \\
\text { altitude flight, } \\
\text { intrusive, } \\
\text { highly trained and } \\
\text { costly staff (pilots) }\end{array}$ \\
\hline Drone & $\begin{array}{c}\text { Flexibility } \\
\text { Reproducibility and } \\
\text { high frequency } \\
\text { assignments of the } \\
\text { missions. } \\
\text { Repeatability } \\
\text { Quality of the } \\
\text { information from } \\
\text { multi-spectral imagers } \\
\text { Access in areas } \\
\text { without endangering } \\
\text { human } \\
\text { Fast execution }\end{array}$ & $\begin{array}{l}\text { Regulatory } \\
\text { requirements on } \\
\text { the conditions of } \\
\text { employment of } \\
\text { civil drones but } \\
\text { which get easier } \\
\text { gradually. } \\
\text { Low payload } \\
\text { weight capability }\end{array}$ \\
\hline
\end{tabular}

Table 1. Forces and weaknesses of the different means of surveying

The different technical means of surveying are exposed in the upper table are complementary: visual inspections by ground means will always be required, but at a different rate.

\section{DIDRO: General description}

The functional requirement is to contribute to the flood surveying and regular dikes surveying outside times of crisis by the use of instrumented drones in addition to ground base means and/or helicopters. The drones must have an electric range of 1 to 4 hours and carrying several kilos of instrumentation.

The experts, distant from 0 to $10 \mathrm{~km}$, shall receive real-time information in a time of crisis and with a delay (a few hours or days) in other cases. These data from the HD multi-spectral and $\mu$ Lidar imagers shall or not be merged into analytics and possibly cross-checked with other geographic, seismic and electrical information. The deliverables are not limited to images as for most of current drone services but also include processed multi spectral signatures. Other current means of surveying systems do not include such multi-spectral analytics. Moreover, they are generally more intrusive.

In crisis situations, the images are transmitted to a central station responsible of their analysis. Where an area is designated by experts as potentially dangerous, the drone pilot can take control of the drone system to redirect it.

\section{DIDRO technological and regulatory challenges}

The various technological locks of this system are listed in the table below:

\begin{tabular}{|c|c|c|}
\hline Partners & Technological locks & Criticality \\
\hline $\begin{array}{l}\text { SURVEY } \\
\text { Copter } \\
\text { DICT } \\
\end{array}$ & $\begin{array}{l}\text { Data link for HD video, flight by } \\
\text { difficult weather and wind conditions, } \\
\text { Anti-collision avoidance system }\end{array}$ & Average \\
\hline $\begin{array}{l}\text { DICT, } \\
\text { IFSTTAR }\end{array}$ & $\begin{array}{l}\text { Payload design meeting regulatory } \\
\text { constraints, constraints of the vector } \\
\text { (weight, versatility) and the system } \\
\text { specifications. }\end{array}$ & High \\
\hline $\begin{array}{l}\text { SURVEY } \\
\text { Copter, } \\
\text { Redbird }\end{array}$ & $\begin{array}{l}\text { Regulation: Flight above urban areas, } \\
\text { compliance with a duly authorized } \\
\text { flight plan. } \\
\text { Discussions with the French Civil } \\
\text { Aviation Administration (DGAC) on } \\
\text { the exemptions for experimental } \\
\text { flights. }\end{array}$ & High \\
\hline $\begin{array}{l}\text { CEREMA } \\
\text { IRSTEA } \\
\text { IGN } \\
\text { IFSTTAR } \\
\text { REDBIRD } \\
\end{array}$ & $\begin{array}{l}\text { Data processing models with } \\
\text { analytics specific to dikes surveying }\end{array}$ & High \\
\hline $\begin{array}{l}\text { CEREMA } \\
\text { IGN Irstea }\end{array}$ & $\begin{array}{l}\text { Detailed modelling and detection of } \\
\text { internal heterogeneity by VNIR, } \\
\text { thermal infrared photogrammetry and } \\
\mu \text { Lidar }\end{array}$ & Average \\
\hline DICT & $\begin{array}{l}\text { Payloads compatible with all models } \\
\text { of drones in the range of the } \\
\text { SURVEY Copter drones. } \\
\text { Develop light mechatronics. } \\
\text { Payload mechanical interface } \\
\text { enabling an easy setup under the } \\
\text { drone even under stress in crisis }\end{array}$ & Average \\
\hline $\begin{array}{l}\text { SURVEY } \\
\text { Copter, } \\
\text { Ifsttar, } \\
\text { DICT }\end{array}$ & $\begin{array}{l}\text { Payload integration within the drone } \\
\text { system, electromagnetic compatibility }\end{array}$ & High \\
\hline Geomatys & $\begin{array}{l}\text { Integration of data processing models } \\
\text { within an IT architecture allowing } \\
\text { scalable processing. BPMN / BIPEL } \\
\text { standards (business processes) and } \\
\text { OpenMI, WPS (models) }\end{array}$ & High \\
\hline Geomatys & $\begin{array}{l}\text { Implementation of a solution for the } \\
\text { acquisition and render of data during } \\
\text { flood event }\end{array}$ & High \\
\hline
\end{tabular}

Table 2. Technological Locks of the DIDRO project.

The drone-based data analytics shall provide specific answers to the needs of dikes managers. These needs differ whether it is a routine inspection or a flood 
situation. The following recurring needs have been assessed within dikes managers in France:

- regarding routine inspection:

- monitoring of the dikes morphology evolution through time: detection of Kartz areas, riprap blocks movement at the dike's base and distortions from an earthquake.

- detection of burrows, cracks, erosion pits dug and ancient breaches.

- At a time of floods:

- detection of water inflow from the inland side of the dikes,

- cracks and landslides detection

- waterline monitoring

The project includes at least two seasons of operational tests, mainly in the Provence-Alpes-Côte d'Azur Region, besides other places in France such as the Loire valley.

Moreover, the DIDRO project should analyse the constraints and dangers that could arise from drone flight above residential areas at a time of floods. These DIDRO flight scenarios will be studied with the French regulatory authorities.

\section{Project organisation}

DIDRO project is certified by the competitiveness clusters RISQUES, ASTECH and PEGASE. It includes the following actors:

\begin{tabular}{|c|c|}
\hline Partners & Role of the partner in the project \\
\hline Redbird & $\begin{array}{l}\text { Project management. Eventual Service Provider } \\
\text { Flight acquisition and data processing }\end{array}$ \\
\hline $\begin{array}{l}\text { SURVEY } \\
\text { Copter }\end{array}$ & $\begin{array}{l}\text { Drones manufacturer (Copter } 4 \text { and DVF 2000) } \\
\text { payload integration, flight test }\end{array}$ \\
\hline Ifsttar & $\begin{array}{l}\text { System Engineering (technical coordinator). } \\
\text { Development and validation of detection, } \\
\text { monitoring methods (geophysical and hydraulic } \\
\text { payload) }\end{array}$ \\
\hline Irstea & $\begin{array}{l}\text { Expertise in dikes engineering and their inspection } \\
\text { and diagnostic methods. } \\
\text { VNIR sensor and data modelling. } \\
\mu \text { Lidar sensor and data modelling - supplier: } \\
\text { L'Avion Jaune }\end{array}$ \\
\hline $\begin{array}{l}\text { France } \\
\text { Digues }\end{array}$ & End user. Specifications and validation \\
\hline DREAL & End user. Specifications and validation \\
\hline CEREMA & $\begin{array}{l}\text { Methods of inspection and auscultation of } \\
\text { structures (with Ifsttar and Irstea). } \\
\text { Interfaces with an instrumented ground-based } \\
\text { vehicles. } \\
\text { Multi-spectral detection of internal disorders }\end{array}$ \\
\hline IGN & $\begin{array}{l}\text { Mapping tools of multi-spectral images (visible, IR } \\
\text { and near-IR). } \\
\text { GeoCube (precise geolocation) and light } \\
\text { photogrammetric camera. }\end{array}$ \\
\hline DICT & $\begin{array}{l}\text { Payload interface and carrier } \\
\text { Doppler effect control tower }\end{array}$ \\
\hline
\end{tabular}

\begin{tabular}{|c|l|}
\hline & Optimization of existing instrumentation \\
\hline Geomatys & $\begin{array}{l}\text { Service interface development expertise and } \\
\text { Software as a Service (SaaS) }\end{array}$ \\
\hline $\begin{array}{c}\text { ENTENTE } \\
\text { Valabre }\end{array}$ & $\begin{array}{l}\text { Expertise in flood risk management. Organisation } \\
\text { of test to assess the capacity of drones during } \\
\text { flooding crisis }\end{array}$ \\
\hline
\end{tabular}

Table 3. Members of the DIDRO consortium.

\section{Key figures of the dikes inspection market}

There are about $8,600 \mathrm{~km}$ of dikes in France, out of which $510 \mathrm{~km}$ are against marine submersion protecting hundreds of thousands, even millions (if other flood defence structures similar to dikes are summed up), against the hazards of flash floods and coastal flooding.

Only 3,000 km are in good shape (CEPRI, European prevention of flood risk Centre, 2011). The $5,600 \mathrm{~km}$ remaining are either in a much deteriorated state, with local disorders, or either their state is not known (for at least $2,000 \mathrm{~km}$ ). Important work is therefore to be considered for $3,000 \mathrm{~km}$ to $5,000 \mathrm{~km}$ of dikes. The risk analyses carried out on some structures by manager's show that the exceedance probabilities of the current flood defence capabilities of dikes correspond to events whose probability is between $1 / 20$ and $1 / 50$ per year. According to the DGPR (French General Directorate for Flood Prevention), one (or more) flood defence structure(s) is (are) seriously damaged every year. Expectations on flood protections are particularly high in urban areas.

Besides the $8,600 \mathrm{~km}$ anti-flood dikes, there are 3760 $\mathrm{km}$ of dikes along channels. These dams are essential for the regional economy.

Another protection landform, dune ridges, sometimes plays a major economic function. For example, the Flèche de la Gracieuse dune ridge in the Rhone Delta is a natural breakwater protecting the Gulf of Fos and the harbour of Marseille. Now these dunes could have very high mobility because of the sea level, waves, and wind. A flexible and fast monitoring by drone is thus particularly suitable.

DIDRO address a global demand outside France. For examples:

- The Netherlands are protected by $6,000 \mathrm{~km}$ of dikes. The 2015 Delta Plan will invest $€ 20$ billion over the next 30 years.

- Germany: Elbe, Danube and Weser rivers are subject to flood hazard. The addressable market is estimated at 1.2 million $€$.

- Italy is affected by flooding in November on the Piave, Serail Chiampo, Ceresone and Aldega river. The addressable market is estimated at 0.8 million euros.

- United States. The Mississippi is particularly contained by levees.

- Quebec. During spring floods, ground patrols are monitoring the levees $24 \mathrm{~h} / 24$. 
- Japan hosts 9,000 km of dikes, especially against tsunamis and for the protection of nuclear power plants.

\section{Conclusion}

DIDRO project aims at providing a new means for dikes surveying in two contexts: routine inspection and inspection before / during / and following a flood event. In France, there are about $8600 \mathrm{~km}$ of dikes, out of which $510 \mathrm{~km}$ are against marine submersion, protecting from hundreds of thousands people, even millions people if the other flood defence structures similar to dikes are taken into account. The implementation of new regulatory requirements has highlighted, besides the disparity of resources, a lack of staff and funds among the dikes managers in France.

The inspection by ground crews is expensive in time and limited in a context of human resource reduction. Ground-based instrumented vehicle, such as the one currently being developed by Cerema (CECP Angers), has the defect of a biased vision of the observed dike and thus cannot produce a comprehensive survey of the structure. Drone offers a new complementary means of surveying which can map broad areas efficiently while being more flexible and easier to operate than other airborne means. During a flood crisis, with real-time information at a high update rate, the drone DIDRO shall serve as a flying patrol, allowing helicopters to devote themselves to critical operations requiring a heavy payload.

DIDRO seeks to bring existing developments on airborne remote sensing by drone on the scope of the project: dikes surveys. The project includes at least two seasons of operational tests, mainly in the ProvenceAlpes-Côte d'Azur Region, besides other places in France such as the Loire valley. It shall eventually end up with an integrated service delivering drone operation as well as the consecutive analytics dedicated to the surveillance, reconnaissance and auscultation of dikes. The project will end in 2018. Market access is then the responsibility of Redbird, the future service provider and will be done with the help of the other members of the DIDRO consortium.

\section{Acknowledgments}

The authors strongly thank:

- France Digues association and the member of the consortium:

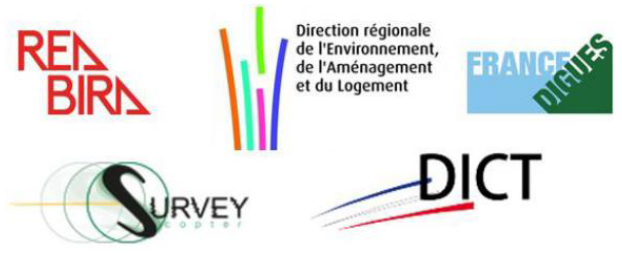

\section{Geomat's irstea} GN INSTITUT NATIONAL
DE LINFORMATION LE TOERAPHIDUE
ET FORESTIERE IFSTTAR ir Cerema

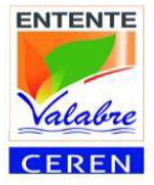

- The clusters which have labelled this project:
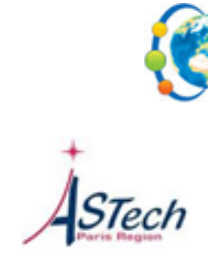

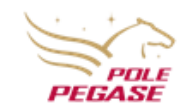

- DIDRO institutional support in the framework of the 19th call for projects of the Fonds Unique Interministériel (FUI)



- Dikes managers which are advising the project: Société du Canal de Provence, France Digues, DREAL Centre, SYMADREM, CNR (Compagnie Nationale du Rhône), VNF, le Grand Port Maritime de Marseille, Parc Naturel du Queyras.

- Dikes Managers which have submitted letters of interest for the inspection service which is developed by DIDRO: besides the abovementionned dikes managers, Conseil Général du Haut Rhin, Conseil Général des Pyrénées Orientales, SMAVD Etablissement Public Territorial du Bassin de la Durance and Chambéry métropole.

- Jean-Michel Tanguy, advisor to the Innovation and Research Director at the French Ministry of Ecology, Sustainable Development and Energy, for his continuous support.

\section{References}

1. CEPRI, Centre européen de prévention du risque d'inondation. (2011). Rapport : La gestion des digues de protection contre les inondations.

2. CIRIA (2013) The International Levee Handbook 
3. Derkx, F., \& Sorin, J.-L. (2015). Quelques essais sur l'eau et l'environnement réalisés à l'aide d'un drone. Congrès SHF.

4. France Digues. (2014). Rapport de synthèse du retour d'expérience sur l'application du décret de 2007.

5. Tourment, R., Peyras, L., Vuillet, M., De Massiac, JC., Allouche, A., Nicolas, L., Casteigts, C., Delaunay, C. (2012) Digsure Method: Decision Support Indicators and GIS Tool for Levees Management. In FloodRisk 2012 - 2nd European Conference on Flood risk Management. Rotterdam, Netherlands, 20th-22nd November 2012. Klijn \& Schweckendiek (eds) (C) 2013 Taylor \& Francis Group, London, ISBN 978-0-415-62144-1

6. Tourment R., Beullac B., Deniaud Y., Simm J., Wallis M.,Sharp M., Pohl R., Van Hemert H. (2013) - De l'EDD des digues en France aux travaux de l'ILH sur les mécanismes élémentaires et les scénarios de défaillance. 2ème colloque national Digues2013, MEDDTL / CFBR / Irstea, Digues Maritimes et Fluviales de Protection contre les Submersions, Aix-en-Provence. pp. 288-297 